ISLAMIC BANKING Volume 4 Nomor 1 Agustus 2018|57

\title{
ANALISIS PEMAHAMAN DAN PENERAPAN ETIKA BISNIS ISLAM PEDAGANG PENGEPUL BARANG BEKAS DI KOTA PALEMBANG
}

\author{
Amir Salim \\ (Dosen Sekolah Tinggi Ekonomi dan Bisnis Syari'ah (STEBIS) \\ Indo Global Mandiri (IGM) Palembang \\ emiros02@gmail.com
}

\section{ABSTRAK}

Dalam era globalisasi ini, perkembangan perekonomian dunia begitu pesat seiring dengan berkembang dan meningkatnya kebutuhan manusia akan sandang, pangan, dan teknologi. Kebutuhan tersebut meningkat sebagai akibat jumlah penduduk yang setiap tahun yang terus bertambah, sehingga menimbulkan persaingan bisnis makin tinggi. Hal ini terlihat dari upaya-upaya yang dilakukan masyarakat dalam rangka memenuhi kebutuhan hidup. Salah satu bentuk upaya masyarakat dalam memenuhi kebutuhan hidup tersebut adalah usaha pemulung dan pengepul barang bekas. Pedagang pengepul barang bekas merupakan perdagangan yang tiada habis masa jenuhnya dalam berdagang, karena dalam perdagangan ini mendaur ulang barang yang masih layak untuk dipergunakan atau mendaur ulang barang bekas sehingga barang tersebut menjadi layak untuk dipergunakan kembali.

Terlepas dari jenis bisnis yang dijalankan, bisnis selalu memainkan peranan penting dalam kehidupan ekonomi dan sosial bagi semua orang disepanjang abad dan semua lapisan masyarakat agama Islam sejak awal lahirnya. Rasulullah memberikan apresiasi yang lebih terhadap kegiatan bisnis. Namun, Rasulullah tidak begitu saja meninggalkan tanpa aturan, kaidah, ataupun batasan yang harus diperhatikan dalam menjalankan perdagangan atau bisnis. Praktek manipulasi tidak akan terjadi jika dilandasi dengan moral yang tinggi. Moral dan tingkat kejujuran yang rendah akan menghancurkan tata nilai etika bisnis itu sendiri. Akan tetapi bagi orang-orang yang berkecimpung dalam bisnis yang dilandasi oleh rasa keagamaan mendalam akan mengetahui bahwa perilaku jujur akan memberikan kepuasan tersendiri dalam kehidupannya. Berbisnis secara etis sangat perlu dilakukan karena profesi bisnis pada hakekatnya adalah profesi luhur yang melayani masyarakat banyak. Usaha bisnis berada di tengah-tengah masyarakat, mereka harus menjaga kelangsungan hidup bisnisnya. Caranya ialah menjalankan prinsip etika bisnis. Etika bisnis Islam bertujuan mengajarkan manusia untuk menjalin kerjasama, tolong menolong dan menjauhkan diri dari sikap dengki dan dendam serta hal-hal yang tidak sesuai dengan syariah.

Adapun rumusan masalah meliputi tentang bagaimana pemahaman etika bisnis Islam pedagang pengepul barang bekas di Palembang dan bagaimana penerapan etika bisnis Islam pedagang pengepul barang bekas di Palembang. Tujuan dari penelitian ini adalah untuk menjelaskan dan menganalisis mengenai pemahaman etika bisnis Islam pedagang pengepul barang bekas di Palembang penerapan etika bisnis Islam pedagang pengepul barang bekas di Palembang.

Akhirnya, setelah melakukan penelitian ini hasilnya menunjukkan bahwa berdasarkan hasil penelitian tentang faktor-faktor yang mempengaruhi pemahaman 
etika bisnis Islam pedagang pengepul barang bekas diantaranya faktor tauhid mempengaruhinya sebesar 78,38 \% dan faktor ihsan sebesar 79,79\%. Pada hasil penelitian tentang faktor-faktor yang mempengaruhi penerapan etika bisnis Islam pedagang pengepul barang bekas diantaranya faktor faktor keseimbangan mempengaruhinya sebesar 83,39\%, faktor kehendak bebas sebesar 78,55\%, dan faktor tanggung jawab sebesar 77,1 \%. Dengan demikian, hasil penelitian faktor-faktor yang mempengaruhi pemahaman dan penerapan etika bisnis Islam pedagang pengepul barang bekas dapat dikategorikan baik.

\section{PENDAHULUAN}

\section{A. Latar Belakang Masalah}

Dalam konteks Islam semua aktivitas harus mengacu pada Al-Qur'an dan Hadist atau Ijtihad para ulama. Bisnis Islam dikendalikan oleh halal dan haram baik dari cara memperolehnya atau pemanfataannya. Islam melarang suatu bentuk transaksi yang akan menimbulkan kesulitan dan masalah, sebuah bentuk transaksi yang hanya semata berdasarkan pada kans dan spekulasi, dimana semua pihak yang terlibat dalam bisnis itu tidak dijelaskan dengan seksama yang akibatnya memungjinkan sebagian dari pihak yang terlibat dapat menarik keuntungan namun dengan merugikan pihak lain. Al-Qur'an sebagai sumber nilai, telah memberikan batasan-batasan umum mengenai nilai-nilai prinsipil yang harus dijadikan acuan dalam berbisnis.

Dalam era globalisasi ini, perkembangan perekonomian dunia begitu pesat seiring dengan berkembang dan meningkatnya kebutuhan manusia akan sandang, pangan, dan teknologi. Salah satu bentuk upaya masyarakat dalam memenuhi kebutuhan hidup tersebut adalah usaha pemulung dan pengepul barang bekas. Sejumlah barang rongsokan bisa didaur ulang dan mendatangkan rupiah. Pedagang pengepul barang bekas merupakan perdagangan yang tiada habis masa jenuhnya dalam berdagang, karena dalam perdagangan ini mendaur ulang barang yang masih layak untuk dipergunakan atau mendaur ulang barang bekas sehingga barang tersebut menjadi layak untuk dipergunakan kembali. Jika dilihat manfaat dari perdagangan ini banyak sekali manfaat yang dapat diambil diantaranya dapat menjaga efek gas rumah kaca akibat pembakaran barang-barang bekas yang tidak di daur ulang kembali.

Terlepas dari jenis bisnis yang dijalankan, bisnis selalu memainkan peranan penting dalam kehidupan ekonomi dan sosial bagi semua orang 
disepanjang abad dan semua lapisan masyarakat agama Islam sejak awal lahirnya. Mengizinkan adanya bisnis karena Rasulallah saw sendiri pada awalnya juga berbisnis dalam jangka waktu yang cukup lama. ${ }^{1}$ Rasulullah memberikan apresiasi yang lebih terhadap kegiatan bisnis, seperti sabda beliau "Perhatikan olehmu sekalian perdagangan, sesungguhnya di dunia ini perdagangan itu ada sembilan dari sepuluh pintu rezeki" ${ }^{2}$ Namun, Rasulullah tidak begitu saja meninggalkan tanpa aturan, kaidah, ataupun batasan yang harus diperhatikan dalam menjalankan perdagangan atau bisnis.

Dalam dunia bisnis semua orang tidak mengharapkan memperoleh perlakuan tidak jujur dari sesamanya. Dalam observasi sementara terhadap pengepul barang bekas khususnya di wilayah Kecematan Kemuning dan Ilir Barat II Palembang, terdapat banyak pembisnis yang menggunakan cara-cara yang tidak pantas dilakukan, antara lain dengan mengurangi timbangan dan menutupi cacat barang. Hal ini tentu saja sangat merugikan pihak lain yang melakukan transaksi dengan para pengepul tersebut. Kenyataan bahwa mayoritas pengepul tersebut beragama Islam, menjadikan hal itu lebih memprihatinkan.

Praktek manipulasi tidak akan terjadi jika dilandasi dengan moral yang tinggi. Moral dan tingkat kejujuran yang rendah akan menghancurkan tata nilai etika bisnis itu sendiri. Akan tetapi bagi orang-orang yang berkecimpung dalam bisnis yang dilandasi oleh rasa keagamaan mendalam akan mengetahui bahwa perilaku jujur akan memberikan kepuasan tersendiri dalam kehidupannya. Berbisnis secara etis sangat perlu dilakukan karena profesi bisnis pada hakekatnya adalah profesi luhur yang melayani masyarakat banyak. Usaha bisnis berada di tengah-tengah masyarakat, mereka harus menjaga kelangsungan hidup bisnisnya. Caranya ialah menjalankan prinsip etika bisnis.

Etika bisnis Islam bertujuan mengajarkan manusia untuk menjalin kerjasama, tolong menolong dan menjauhkan diri dari sikap dengki dan dendam serta hal-hal yang tidak sesuai dengan syariah ${ }^{3}$. Etika bisnis dalam Islam juga berfungsi sebagai controlling (pengatur) terhadap aktifitas ekonomi pedagang, karena secara filosofi etika mendasarkan diri pada nalar ilmu dan agama untuk

\footnotetext{
${ }^{1}$ Alwi Shihab, Islam inklusif. Bandung: Mizan. h.172. 1992

${ }^{2}$ Achyar Eldine, Etika Bisnis Islam, Jurnal Khazanah, Vol 3 No 3, Edisi Oktober, h282, 2007.

3 Yusuf Qordhowi. Norma dan Etika Ekonomi Islam. Jakarta : Gema Insani Press.h 145. 1993
} 
menilai. Landasan penilaian ini dalam praktek kehidupan di masyarakat sering kita temukan bahwa secara agama terdapat nilai mengenai hal-hal yang baik atau buruk, seperti pihak yang mendzhalimi dan terdzhalimi ${ }^{4}$.

Dengan kenyataan di atas maka prinsip pengetahuan dan pemahaman akan etika bisnis Islam mutlak harus dimiliki oleh setiap individu yang melakukan kegiatan ekonomi baik itu seorang pebisnis atau pedagang dalam menjalankan aktivitas ekonominya, untuk menghindarkan diri dari berbagai macam tindakan yang dilarang oleh Allah. Dunia bisnis yang baik yang mendapat ridho Allah haruslah menjunjung nilai-nilai etika dan moral, sehingga hasil yang bersih dan mendapat berkah baik di dunia maupun di akhirat.

Berdasarkan uraian di atas, penulis tertarik untuk melakukan penelitian terhadap etika bisnis Islam pedagang pengepul barang bekas, khususnya yang ada di Kota Palembang.

\section{B. Kerangka Teori}

Pada masa Rasulullah, nilai-nilai moralitas sangat diperhatikan dalam kehidupan perdagangan. Bahkan sampai pada masa awal kerasulannya, adalah seorang pedagang yang aktif, dan kemudian menjadi seorang pengawas pasar yang cermat sampai akhir hayatnya. Rasulullah saw telah memulai pengalaman dagangnya sejak usia 12 tahun $^{5}$.

Pasar mendapatkan kedudukan yang penting dalam perekonomian Islam, Rasulullah sangat menghargai harga yang dibentuk oleh pasar sebagai harga yang adil. Oleh karena itu, Islam menekankan adanya moralitas seperti persaingan yang sehat, kejujuran, keterbukaan, dan keadilan. Implementasi nilai-nilai tersebut merupakan tanggung jawab bagi setiap pelaku pasar. Bagi seorang muslim, nilainilai ini ada sebagai refleksi dari keimanannya kepada Allah, bahkan Rasulullah memerankan dirinya sebagai muhtasib di pasar, dan menegur langsung transaksi perdagangan yang tidak mengindahkan moralitas.

Dengan mengacu pada Al-Qur'an dan praktek kehidupan perdagangan pada masa Rasulullah dan para sahabatnya, Ibnu Taymiyah menyatakan bahwa ciri khas kehidupan perdagangan yang Islami adalah :

\footnotetext{
${ }^{4}$ Muslich, Etika Bisnis Islam, (Jakarta : EKONISIA, 2004), cet 1, h.29

${ }^{5}$ Afzalurrahman. Muhammad Sebagai Pedagang, terj. Dewi Nurjulianti, Jakarta: Yayasan Swarna Bhumy , h 5, 1997
} 
1. Orang harus bebas keluar masuk pasar. Memaksa orang untuk menjual barang dagangan tanpa ada kewajiban untuk menjual merupakan tindakan tidak adil dan ketidakadilan itu dilarang.

2. Adanya informasi yang cukup mengenai kekuatan-kekuatan pasar dan barangbarang dagangan.

3. Unsur-unsur monopolistik harus dilenyapkan dari pasar. Kolusi antar penjual dan pembeli harus dihilangkan. Pemerintah dibolehkan melakukan intervensi.

4. Adanya kenaikan dan penurunan harga yang disebabkan oleh naik turunnya tingkat permintaan dan penawaran.

5. Adanya homogenitas dan standarisasi produk agar terhindar dari pemalsuan produk, penipuan, dan kecurangan kualitas barang.

6. Terhindar dari penyimpangan terhadap kebebasan ekonomi yang jujur, seperti sumpah palsu, kecurangan menakar, dan niat yang buruk dalam perdagangan. Pelaku pasar juga dilarang menjual barang-barang yang haram. ${ }^{6}$

Islam mengajarkan agar dalam jual beli baik penjual dan pembeli masingmasing mendapatkan keuntungan. Pembeli beruntung karena mendapatkan barang yang dibutuhkan dengan harga wajar, sedangkan penjual beruntung karena mendapatkan penghasilan atau untung yang wajar sebagai balasan dalam mengadakan barang yang dijualnya.

Maka dalam jual beli hendaknya ada unsur suka sama suka antara penjual dan pembeli, sehingga tidak ada paksaan dalam praktik jual beli tersebut. Ada beberapa prinsip yang harus diperhatikan oleh pedagang. Prinsip-prinsip tersebut merupakan interprestasi dari makna 'antaradhin minkum dan latazlumma walatuzlamun, yaitu :

1. Penipuan. Kondisi ideal dalam sebuah pasar adalah apabila penjual dan pembeli mempunyai informasi yang sama tentang barang yang akan diperjualbelikan. Apabila salah satu pihak tidak mempunyai informasi seperti yang dimiliki oleh pihak lain, maka salah satu pihak lain, maka salah satu pihak akan merasa dirugikan dan terjadi kecurangan atau penipuan.

\footnotetext{
${ }^{6}$ Akhmad Mujahidin, Etika Bisnis Dalam Islam “Analisis Terhadap Aspek Moral Pelaku Bisnis”, Jurnal Hukum Islam, Vol IV No.2, h. 122, Desember 2005.
} 
2. Ketidakjelasan. Tipuan atau tindakan yang bertujuan untuk merugikan pihak lain. Suatu akad mengandung unsur penipuan, karena tidak ada kepastian, baik mengenai ada atau tidaknya obyek akad, besar kecil jumlah maupun menyerahkan obyek akad tersebut.

3. Sumpah palsu. Termasuk juga dalam perbuatan menipu ialah perbuatan bersumpah dengan nama Allah dengan tujuan melariskan barang jualannya. Seperti menyatakan "demi Allah, barang ini adalah paling murah dijual di kota ini dan saya hanya menjual harga modal saja".

4. Menjelekan mitra bisnis. Salah satu cara menjatuhkan lawan bisnis adalah dengan menganggu konsumen agar tidak beralih pada barang yang diperdagangkanya, baik dengan menurunkan harga atau menganggu harga orang lain dengan beragam cara sehingga pembeli beralih. Perilaku menjatuhkan mita bisnis dalam perdagangan merupakan perilaku syaithaniyah yang membawa kehancuran bisnis secara kolektif. Karena berimplikasi pada ketidak percayaan pelanggan atau konsumen terhadap pasar tersebut.

Perilaku konsumen dapat didefinisikan sebagai kegiatan-kegiatan individu yang secara langsung terlibat dalam mendapatkan, mengkonsumsi, dan menghabiskan produk atau jasa ${ }^{7}$, selain itu ada yang menjelaskan bahwa perilaku konsumen sebagai interaksi dinamis antara pengaruh kognisi(pikiran), perilaku, dan kejadian di sekitar kita, di mana manusia melakukan asperk pertukaran dalam hidup mereka ${ }^{8}$.

Keberagaman harapan pelanggan secara literatur dapat diterangkan dalam sembilan faktor, yaitu harga, kelengkapan produk, keunikan, kenyamanan, dapat dipercaya, kualitas, pelayanan, nilai uang, informasi yang dapat dipercaya, dan tempat yang tepat untuk berbelanja ${ }^{9}$. Selain itu, kepuasan atau ketidakpuasan pelanggan adalah respons pelanggan terhadap evaluasi ketidaksesuaian yang dirasakan antara harapan sebelumnya dan kinerja aktual produk yang dirasakan setelah pemakaiannya ${ }^{10}$. Mengemukakan bahwa kepuasan pelanggan adalah

\footnotetext{
7. James F Engel, Blackwell, Roger D., and Miniard, Paul W. Perilaku Konsumen. Terjemahan Budiyanto. Jakarta : Binarupa Aksara. 1994.

8. J Paul Peter., and Jerry C Olson. Consumer Behavior. Perilaku Konsumen dan Strategi Pemasaran. Terjemahan Damos Sihombing. Jakarta : Jilid. Edisi 4, Erlangga. 2000.

9 . Omar, O. E. Retail Marketing. Harlow, England : Perason Education. 1999.

${ }^{10}$. Eric Arnould, Price, Linda., and George Zinkhan. Consumers. New York : Firt Edition,
} 
tingkat perasaan seseorang ssetelah membandingkan kinerja (hasil) yang ia rasakan dibandingkan dengan harapannya ${ }^{11}$. Demikian halnya pendapat menyatakan, bahwa kepuasan atau ketidakpuasan pelanggan merupakan suatu tanggapan emosional setelah mengevaluasi kinerja produk atau jasa ${ }^{12}$.

Etika adalah bagian dari filsafat yang membahas secara rasional dan kritis tentang nilai, norma atau moralitas. Dengan demikian, moral berbeda dengan etika. Norma adalah suatu pranata dan nilai mengenai baik dan buruk, sedangkan etika adalah refleksi kritis dan penjelasan rasional mengapa sesuatu itu baik dan buruk. Menipu orang lain adalah buruk. Ini berada pada tataran moral, sedangkan kajian kritis dan rasional mengapa menipu itu buruk apa alasan pikirannya, merupakan lapangan etika.

Di Indonesia, pengabaian etika bisnis sudah banyak terjadi khususunya oleh para konglomerat. Para pengusaha dan ekonom yang kental kapitalisnya, mempertanyakan apakah tepat mempersoalkan etika dalam wacana ilmu ekonomi. Munculnya penolakan terhadap etika bisnis, dilatari oleh sebuah paradigma klasik, bahwa ilmu ekonomi harus bebas nilai (value free). Etika bisnis hanyalah mempersempit ruang gerak keuntungan ekonomis. Padahal, prinsip ekonomi, menurut mereka, adalah mencari keuntungan yang sebesar-besarnya.

Islam menawarkan keterpaduan agama, ekonomi, dan sosial demi membentuk kesatuan. Atas dasar pandangan ini pula maka etika dan bisnis menjadi terpadu, vertikal maupun horizontal, membentuk suatu persamaan yang sangat penting dalam sistem Islam. Realitasnya, para pelaku bisnis sering tidak mengindahkan etika. Para pelaku bisnis yang sukses memegang prinsip-prinsip bisnis yang tidak bermoral, misalnya maksimalisasi laba, agresivitas, individualitas, semangat persaingan, dan manajemen konflik. Etika atau moral dalam bisnis merupakan buah dari keimanan, keislaman dan ketakwaan yang didasarkan pada keyakinan akan kebenaran Allah SWT.

McGraw-Hill. 2003.

11. Philp Kotler dan Gary Amstrong. Dasar-Dasar Pemasaran (Principle of Marketing 7e). Jilid I dan II, Penerbit Prenhallindo, Jakarta. 1997.

${ }^{12}$. William L Wilkie. Consumer Behavior. New York : Third Edition, John Wilem \& Sons Inc. 1994. 
64 | Amir Salim Analisis Pemahaman dan Penerapan Etika Bisnis Islam...

Dengan demikian, kerangka teori di atas merupakan landasan pemikiran penulis untuk memperkuat pembahasan penelitian ini.

\section{Metode Penelitian}

\section{Jenis atau Desain Penelitian}

Jenis penelitian yang digunakan pada penelitian ini adalah kausalitas, yaitu tipe penelitian dengan karakteristik masalah berupa hubungan sebab akibat antara dua variabel atau lebih. Jenis ini digunakan untuk menjelaskan pengaruh tauhid, keseimbangan, kehendak bebas, tanggung jawab, dan ihsan terhadap etika bisnis Islam pedagang pengepul barang bekas di wilayah Kecematan Kemunig dan Ilir Barat II Kota Palembang.

\section{Tempat dan Waktu Penelitian}

Penelitian akan dilaksanakan pada pedagang yang berada di wilayah Kecematan Kemuning dan Ilir Barat II. Waktu penelitian ini dimulai pada bulan Juni sampai Agustus 2016 dari tahap awal sampai tahap akhir.

\section{Populasi dan Sampel Penelitian}

Populasi adalah keseluruhan subjek penelitian ${ }^{13}$. Dalam hal ini peneliti mengambil populasi pedagang pengepul barang bekas yang berjumlah 100 orang di wilayah Kecamatan Kemuning dan Ilir Barat II kota Palembang. Dalam hal ini peneliti akan mengambil sampel pedagang pengepul barang bekas yang berada di wilayah Kecematan Kemuning dan Ilir Barat II. Dalam penelitian ini pengambilan sampel dapat menggunakan Rumus Slovin (dalam Ridwan : 2005:65) :

$\mathrm{n}=\frac{N}{N\left(d^{2}\right)+1}$

\section{Variabel Penelitian}

Variabel penelitian adalah objek penelitian, atau apa yang menjadi titik perhatian suatu penelitian. Yang menjadi variabel dalam penelitian ini adalah aktivitas etika bisnis Islam pedangang pengepul barang bekas. Faktor-faktor yang mempengaruhi etika bisnis islam yaitu tauhid, keseimbangan, kehendak bebas, tanggung jawab, dan ihsan.

${ }^{13}$. Arikunto, Suharsimi. Prosedur Penelitian. Jakarta : Rineka Cipta. Hal 173, 2010. 


\section{Teknik dan Instrumen Pengumpulan Data}

Dalam penelitian ini menggunakan teknik pengumpulan data yang berupa angket atau kuesioner. Angket atau kuesioner adalah suatu alat pengumpul data yang berupa serangkai pertanyaan yang diajukan pada responden untuk mendapatkan jawaban.

\section{Teknik Pengukuran Variabel}

Alat yang digunakan untuk mengumpulkan data dalam penelitian ini adalah angket atau kuesioner. Peneliti menggunakan kuesioner menggunakan skala yang digunakan dalam penelitin ini adalah skala likert. Skala ini berinterasi 1-5 dengan pilihan jawaban sebagai berikut :

○ ( 1 ) Sangat Tidak Setuju (STS)

○ ( 2 ) Tidak Setuju (TS)

○ ( 3 ) Netral (N)

○ ( 4 ) Setuju (S)

○ ( 5 ) Sangat Setuju (SS)

\section{Instrumen Penelitian}

\section{a. Validitas Instrumen}

Validitas adalah suatu ukuran yang menunjukkan tingkat-tingkat kevalidan atau kesahihan suatu instrumen. Sebuah instrumen dikatakan valid apabila mampu mengukur apa yang diinginkan. Pengukuran pada analisis butir yaitu dengan cara skor-skor yang ada kemudian dikorelasikan dengan menggunakan Rumus korelasi product moment sebagai berikut ${ }^{14}$ :

$$
\mathrm{r}_{\mathrm{xy}}=\frac{N \sum X Y-\left(\sum X\right)\left(\sum Y\right)}{\sqrt{\left\{N \cdot \sum X^{2}-\left(\sum X\right)^{2}\right\}\left\{N \cdot \sum^{2}-\left(\sum Y\right)^{2}\right\}}}
$$

\section{b. Uji Reliabilitas}

Reliabilitas menunjukkan pada satu pengertian bahwa sesuatu instrumen cukup dapat dipercaya untuk digunakan sebagai alat pengumpul data karena instrumen tersebut sudah baik. Dalam penelitian ini uji reliabilitas dilakukan dengan menggunakan tekhnik formula Alpha :

$$
\mathrm{r}_{11}=\left(\frac{k}{k-1}\right)\left(1-\frac{\sum \sigma_{b}^{2}}{\sigma_{t}^{2}}\right)
$$

\footnotetext{
14 . .Arikunto, Suharsimi. Prosedur Penelitian. Jakarta : Rineka Cipta. Hal 213, 2010.
} 


\section{HASIL PENELITIAN}

Berdasarkan hasil penelitian dapat diketahui bahwa pada faktor-faktor yang mempengaruhi pemahaman dan penerapan etika bisnis Islam pedagang pengepul barang bekas terdapat lima faktor yang mempengaruhinya. Faktor-faktor tersebut adalah faktor tauhid, faktor keseimbangan, faktor kehendak bebas, faktor tanggung jawab, dan faktor ihsan. Pada penelitian pemahaman etika bisnis Islam pedagang pengepul barang bekas terdapat dua faktor yaitu pertama faktor tauhid yang terdiri dari shalat, zakat, dan beda suku, kedua faktor ihsan yang terdiri dari kerjasama dan pelayanan. Pada penelitian penerapan etika bisnis Islam pedagang pengepul barang bekas terdapat tiga faktor yaitu pertama faktor keseimbangan yang terdiri dari timbangan dan kondisi barang, kedua faktor kehendak bebas yang terdiri dari persaingan sehat, dan memainkan harga, ketiga faktor tanggung jawab yang terdiri dari buku kas, hutang piutang, dan barang titipan.

1. Faktor-Faktor yang Mempengaruhi Pemahaman Etika Bisnis Islam Pedagang Pengepul Barang Bekas

Di dalam penelitian pemahaman etika bisnis Islam pedagang pengepul barang bekas terdapat dua faktor yaitu faktor tauhid dan faktor ihsan. Faktor tauhid, konsep ini dimaksudkan bahwa sumber utama etika Islam adalah kepercayaan total dan murni terhadap keesaan Tuhan. Dengan mengintegrasikan aspek religius dengan aspek-aspek lainnya, seperti ekonomi, akan menimbulkan perasaan dalam diri manusia bahwa ia akan selalu merasa direkam segala aktivitas kehidupannya, termasuk dalam aktivitas berekonomi sehingga dalam melakukan segala aktivitas bisnis tidak akan mudah menyimpang dari segala ketentuanNya. Faktor ihsan, keinginan kuat berbuat baik untuk sesama manusia dengan setulus-tulusnya hanya karena pertanggungjawaban kepada Allah. Fungsi ihsan dalam agama sebagai alat control dan evaluasi terhadap bentukbentuk kegiatan ibadah, sehingga aktivitas manusia akan lebih terarah dan maju. Fungsi tersebut selaras dengan definisinya sendiri yaitu, ketika engkau beribadah kepada Allah seolah-olah engkau melihat-Nya, apabila engkau tidak mampu melihat-Nya maka sesungguhnya Allah melihat (mengontrol) engkau. Ketika tindakan ekonomi didasari dengan ihsan maka akan melahirkan sifat-sifat positif dan produktif antara lain. Pertama, amanah (jujur) sifat ini muncul dari penghayatan ihsan. Bagi pelaku ekonomi yang memiliki sifat amanah akan mengakui dengan penuh kesadaran bahwa seluruh komponen ekonomi, pikiran, tenaga, harta, dan segalanya adalah milik dan titipan 
Allah, sehingga dalam menjalani aktivitas usaha akan berhati-hati dan waspada serta terhindar dari sipat ceroboh dan sombong karena pemilik perusahaan itu adalah Allah SWT. Kedua, sabar diartikan sebagai sikap tangguh dalam menghadapi seluruh persoalan kehidupan termasuk dalam berekonomi. Sifat ini muncul dari proses panjang aktivitas ibadah yang senantiasa diawasi dan dievaluasi oleh Allah. Dalam seluruh proses tindakan usaha tidak akan lepas dari kendala dan problem, maka kesabaran mutlak dibutuhkan. Dengan sifat ini sebesar apapun problem usaha akan disikapi dengan pikiran-pikiran positif dan hati yang jernih. Ketiga, tawakal diartikan sikap mewakilkan atau menyerahkan penuh segala hasil usaha kepada Allah SWT. Sikap tersebut muncul dari nilai-nilai ihsan. Islam tidak melarang pelaku bisnis mendapatkan keuntungan dalam usahanya. Akan tetapi hasil usaha yang dilakukan oleh seseorang masih bersifat relative, bisa untung atau rugi. Bagi pelaku usaha yang menyerahkan segala hasil kepada Allah tidak punya beban mental yang berlebihan dan ketika hasilnya untung tidak akan lupa diri dan apaila rugi tidak akan pesimis dan putus asa. Keempat, qanaah dalam berekonomi diartikan sebagai sikap efesiensi dan sederhana dalam tindakan usaha. Sikap ini terbentuk dari interaksi yang kuat antara hamba dengan sang khalik. Efisiensi dalam seluruh tindakan ekonomi sangat penting untuk mengurangi dan menekan beban pembiyayaan usaha, sehingga kalau Usaha yang dilakukan itu bidang produksi maka akan menghasilkan prodak yang murah. Demikian pula sikap qanaah terhadap hasil berupa keuntungan ia akan membelanjakan harta yang dimilikinya sesuai dengan kebutuhan pokok terhindar dari sikap boros dan mubadzir. Kelima, wara dalam berekonomi diartikan sikap berhati-hati dalam seluruh tindakan ekonomi. Sikap ini tumbuh dari kesadaran penuh terhadap pengawasan Allah yang sangat ketat dan teliti. Kehati-hatian sangat dibutuhkan oleh para pelaku usaha, mulai dari membuat planning, operasional dan mengontrol usaha dan akan menjauhkan pelaku bisnis dari sikap ceroboh. Ketika hal ini terwujud maka akan tercipta pelaku bisnis profesianal yang shaleh dan tatanan ekonomi yang mapan, sehat, kondusif dan produktif.

Dengan iman, maka lahirlah kesadaran untuk saling menghargai, saling menghormati, dan saling mengingatkan tentang yang benar itu benar dan salah tetap salah, tanpa dibarengi dengan kehendak untuk memaksakan pendiriannya. Berikut ini hasil data penelitian pemahaman etika bisnis Islam pedagang pengepul barang bekas di Palembang : 
a. Faktor Tauhid

$$
\begin{aligned}
\mathrm{P} & =\frac{f}{N} \times 100 \% \\
& =\frac{2822}{3600} \times 100 \% \\
& =78,38 \%
\end{aligned}
$$

b. Faktor Ihsan

$$
\begin{aligned}
\mathrm{P} & =\frac{f}{N} \times 100 \% \\
& =\frac{1915}{2400} \times 100 \% \\
& =79,79 \%
\end{aligned}
$$

Di dalam penelitian pemahaman etika bisnis Islam pedagang pengepul barang bekas faktor tauhid yang meliputi shalat, zakat, dan beda suku dapat mempengaruhi etika bisnis Islam pada pedagang penngepul barang bekas sebesar 78,38 \% dan faktor ihsan meliputi kerjasama dan pelayanan dapat mempengaruhi etika bisnis Islam pada pedagang pengepul barang bekas sebesar 79,79 \%. Ini berarti, faktor tauhid dan faktor ihsan dapat mempengaruhi etika bisnis Islam pada pedagang pengepul barang bekas. Dalam penelitian ini faktor tauhid dan faktor ihsan dapat dikategorikan baik karena di dalam etika bisnis pedagang memahami faktor tersebut.

2. Faktor-Faktor yang Mempengaruhi Penerapan Etika Bisnis Islam Pedagang Pengepul Barang Bekas

Di dalam penelitian penerapan etika bisnis Islam pedagang pengepul barang bekas terdapat tiga faktor yaitu faktor keseimbangan, kehendak bebas, dan tanggung jawab. Penerapan faktor keseimbangan berlaku baik secara harfiah maupun kias dalam dunia bisnis. Sebagai contoh, Allah SWT memperingatkan para pengusa muslim untuk "sempurnakanlah takaranmu apabila kamu menakar dan timbanglah dengan cara yeng benar : itulah lebh utama dans lebih baik akibatnya”. Sangat menarik untuk mengetahui bahwa mkana lain kata ' $a d l$ adalah keadilan keseteraan. Seperti yang kita lihat pada ayat diatas, sebuah transaksi yang seimbang adalah juga setara dan adil. Qur'an mempergunkan istilah 'adl dalam penegertian ini secara keseluruhan, Islam sebenarnya tidak ingin menciptakan sebuah masyarakat pedagang syahid, yang berbisnis semata demi alasan kedermawaan. Sebaliknya, Islam ingin mengekang kecenderungan sikap srakah manusia dan kecintaannya untuk memiliki barang-barang. 
Sebagai akibatnya, baik sikap kikir, maupun boros keduanya dikutuk baik dalam Qur'an maupun hadist.

Berdasarkan konsep kehendak bebas, manusia memiliki kebebasan untuk membuat kontrak dan menempatinya ataupun mengingkarinya. Seorang muslim, yang telah menyerahkan hidupnya pada kehendak Allah SWT, akan menepati semua kontrak yang telah dibuatnya. "Hai orang-orang yang beriman! Penuhilah semua perjanjian itu”. Penting untuk di catat bahwa Allah SWT memerintahkan ayat diatas secara eksplisit kepada kaum muslim. Sebagaimana dikemukakan oleh yusuf 'ali, kata 'uqud adalah sebuah konstruksi multidimensional. Kata tersebut mengandung arti antara lain kewajiban suci yang muncul dari kodrat spiritual dan hubungan kita dengan Allah SWT, kewajiban sosial kita seperti misalnya dalam perjanjian perkawinan, kewajiban politik kita seperti misalnya perjanjian hukum., kewajiban bisnis kita seperti misalnya kontrak formal mengenai tugas-tugas tertentu yang harus dilakukan ataupun kontrak yang tak tertulis mengenai perlakuan layat yang harus diberikan pada para pekerja. Kaum muslim harus mengekang kehendak bebasnya untuk bertindak berdasarkan aturan-aturan moral seperti yang telah digariskan Allah SWT.

Penerapan tanggung jawab. Jika seorang pengusaha muslim berperilaku secara tidak etis, ia tidak dapat menyalahkan tindakanya pada persoalan tekanan bisnis ataupun pada kenyataan bahwa setiap orang juga berperilaku tidak etis. Ia harus memikul tanggung jawab tertinggi atas tindakanya sendiri. Berkaitan dengan hal ini, Allah berfirman "Tiap-tiap diri bertanggung jawab atas apa yang telah diperbuatnya". Karena, konsep ini berkaitan erat dengan konsep kesatuan, keseimbangan dan kehendak bebas. Semua kewajiban harrus dihargai keculai jika seorang moral salah. Sebaai contoh, Ibrahim As menolak kewajiban keluarganya ketika ayahnya menginkan untuk berbuat shirik atau memuja berhala. Di sisi lain, Rasulullah Saw melaksanakan kesepakatan dalam perjanjian Hudaybiyah meskipun hal hal itu berarti bahwa Abu Jandal, seorang yang baru menjadi muslim, harus dikembalikan pada suku Qurash. Sekali seorang muslim mengucapkan janjinya atau terlibat dalam sebuah perjanjian yang sah, maka ia harus menepatinya. "Rasulullah Saw (semoga rahmat terlimpah kepadanya) berkata," tanda-tanda orang munafik ada tiga : 1) apabila berkata ia berdusta. 2) apabila berjani, tidak dipenuhi, dan 3) bila diberi dimanati, ia berkhianat". 
70 | Amir Salim Analisis Pemahaman dan Penerapan Etika Bisnis Islam...

Tanpa mengabaikan kenyataan bahwa ia sepenuhnya dituntun oleh hukum yang diciptakan Allah SWT, ia diberi kemampuan untuk berpikir dan membuat keputusan, memilih jalan hidup yang diinginkan, dan yang paling penting untuk bertindak berdasarkan aturan yang ia pilih. Agar tercipta mekanisme pasar yang sehat, aktivitas ekonomi dalam konsep ini diarahkan untuk kebaikan setiap kepentingan seluruh komunitas Islam yaitu dengan adanya larangan-larangan mengenai monopoli, kecurangan, dan praktik riba. Seorang Muslim yang percaya pada kehendak Allah, akan senantiasa mengabaikan larangan-laranganNya. Ia merupakan bagian kolektif dari masyarakat dan mengakui bahwa Allah meliputi kehidupan individual dan sosial. Dengan demikian, kebebasan berkehendak berhubungan erat dengan kesatuan dan keseimbangan.

Berikut ini hasil data penelitian pemahaman etika bisnis Islam pedagang pengepul barang bekas di Palembang :

a. Faktor keseimbangan

$$
\begin{aligned}
\mathrm{P} & =\frac{f}{N} \times 100 \% \\
& =\frac{2335}{2800} \times 100 \% \\
& =83,39 \%
\end{aligned}
$$

b. Faktor Kehendak Bebas

$$
\begin{aligned}
\mathrm{P} & =\frac{f}{N} \times 100 \% \\
& =\frac{1571}{2000} \times 100 \% \\
& =78,55 \%
\end{aligned}
$$

c. Faktor Tanggung Jawab

$$
\begin{aligned}
\mathrm{P} & =\frac{f}{N} \times 100 \% \\
& =\frac{1542}{2000} \times 100 \% \\
& =77,1 \%
\end{aligned}
$$

Di dalam penelitian penerapan etika bisnis Islam pedagang pengepul barang bekas faktor keseimbangan yang meliputi timbangan dan kondisi barang dapat mempengaruhi etika bisnis Islam pada pedagang penngepul barang bekas sebesar 83,39 $\%$, faktor kehendak bebas meliputi persaingan sehat dan memainkan harga dapat 
mempengaruhi etika bisnis Islam pada pedagang pengepul barang bekas sebesar 78,55 $\%$, dan faktor tanggung jawab meliputi buku kas, hutang-piutang, dan barang titipan dapat mempengaruhi etika bisnis Islam pada pedagang pengepul barang bekas sebesar $77,1 \%$, Ini berarti, faktor keseimbangan, kehendak bebas, dna tanggung jawab dapat mempengaruhi etika bisnis Islam pada pedagang pengepul barang bekas. Dalam penelitian ini faktor keseimbangan, kehendak bebas, dna tanggung jawab dapat dikategorikan baik karena di dalam etika bisnis pedagang menerapkan faktor tersebut.

Dengan demikian, faktor yang mempengaruhi pemahaman dan penerapan etika bisnis Islam pedagang pengepul barang bekas dapat disimpulkan. Faktor yang paling tinggi adalah faktor keseimbangan dengan persentasi 83,39 \%, kemudian faktor ihsan dengan persentasi 79,79 \%, dilanjutkan dengan faktor kehendak bebas dengan persentasi 78,55 \%, faktor tauhid dengan perentasi 78,38 \%, dan faktor tanggung jawab dengan persentasi $77,1 \%$.

\section{PENUTUP}

Faktor-faktor yang mempengaruhi pemahaman dan penerapan etika bisnis Islam pedagang pengepul barang bekas dalam hal ini diantaranya (1) Tauhid, (2) Keseimbangan, (3) Kehendak Bebas, (4) Tanggung jawab, (5) Ihsan. Adapun Tauhid dan Ihsan dapat dijadikan untuk menganalisis pemahaman pada pedagang pengepul barang bekas dan tiga faktor lainnya yaitu Keseimbangan, Kehendak bebas, dan Tanggung jawab dapat dijadikan alat untuk menganalisis penerapan etika bisnis Islam pada pengepul barang bekas. Dari hasil penelitian ini dapat ditarik kesimpulan sebagai berikut :

Faktor-Faktor yang Mempengaruhi Pemahaman Etika Bisnis Islam Pedagang Pengepul Barang Bekas. Berdasarkan hasil penelitian tentang faktor-faktor yang mempengaruhi pemahaman etika bisnis Islam pedagang pengepul barang bekas diantaranya faktor tauhid mempengaruhinya sebesar 78,38 \% dan faktor ihsan sebesar 79,79\%. Dengan demikian, hasil penelitian faktor-faktor yang mempengaruhi pemahaman etika bisnis Islam pedagang pengepul barang bekas dapat dikategorikan baik.

Faktor-Faktor yang Mempengaruhi Penerapan Etika Bisnis Islam Pedagang Pengepul Barang Bekas. Pada hasil penelitian tentang faktor-faktor yang mempengaruhi penerapan etika bisnis Islam pedagang pengepul barang bekas diantaranya faktor faktor keseimbangan mempengaruhinya sebesar 83,39 \%, faktor kehendak bebas sebesar 78,55 
$\%$, dan faktor tanggung jawab sebesar $77,1 \%$. Dengan demikian, hasil penelitian faktor-faktor yang mempengaruhi penerapan etika bisnis Islam pedagang pengepul barang bekas dapat dikategorikan baik.

\section{DAFTAR PUSTAKA}

1. Afzalurrahman. Muhammad Sebagai pedagang, terj. Dewi Nurjulianti. Jakarta: Yayasan Swarna Bhumy. 1997.

2. Alma, Buchari. Dasar-Dasar Etika Bisnis Islam. Bandung : Alfabeta. 2003.

3. Ananda, Faisar. dkk. Islamic Business And Economic Ethics Mengacu Pada Al Quran dan Mengikuti Jejak Rasulullah SAW dalam Bisnis, Keuangan, dan Ekonomi. Jakarts : Bumi Aksara. 2012.

4. Arnould, Eric., Price, Linda., and George Zinkhan. Consumers. New York : Firt Edition, McGraw-Hill. 2003.

5. Ash-Shieddieqy T.M. Hasbi. Pengantar Fiqh Muamalah. Jakarta : Bulan Bintang. 1984.

6. Assauri, Sofjan. Manajemen Pemasaran. Jakarta : PT. Raja Grafindo Persada. 2011.

7. Amrullah. Etika Bisnis Islam (Studi Kasus pada Koperasi Harapan Jaya Kota Sekayu. Pasca Sarjana Konsentrasi Hukum Islam. UIN Raden Fatah : Palembang. 2011.

8. Arikunto, Suharsimi. Prosedur Penelitian Suatu Pendekatan Praktik. Jakarta : Rineka Cipta. 2010.

9. Badrroen, Faisal. Etika Bisnis Islam. Jakarta : Kencana Prenada Media Group. 2006.

10. Charis, Achmad Zubair. Kuliah Etika . (Rajawali Press) Ed III. 1995

11. Djuwaini, Dimyauddin. Pengantar Fiqh Muamalah. Yogyakarta: Pustaka Pelajar. 2010.

12. Engel, James F., Blackwell, Roger D., and Miniard, Paul W. Perilaku Konsumen. Terjemahan Budiyanto. Jakarta : Binarupa Aksara. 1994.

13. Eldine, Achyar. Etika Bisnis Islam, Jurnal Khazanah. Bandung. 2000.

14. Ernawan Erni, R. Business Ethics, Bandung : Alfabeta. 2007.

15. Fahmi, Irfan. Etika Bisnis. Bandung : Alfabeta. 2014.

16. Gregory, N. Mankiw. Makroekonomi. Fitria Liza dan Imam Nurmawan Terjemahan. Jakarta : Erlamngga. Edisi Keenam.

17. Hery, Musnur. Agama dan Etos Kerja Pedagang Pakaian Jadi Etnis Minang di Pasar 16 Ilir Palembang. Pusat Penelitian UIN Raden Fatah : Palembang. 2001. 
18. Indriantoro Nur dan Bambang Supomo. Metodologi Penelitian Bisnis. Yogyakarta : BPFE. 1999.

19. Islahi A A. Konsepsi Ekonomi Ibnu Taimiyah. Surabaya : Bina Ilmi. 1997.

20. Kotler, Philp dan Gary Amstrong. Dasar-Dasar Pemasaran (Principle of Marketing 7e). Jilid I dan II, Penerbit Prenhallindo, Jakarta. 1997.

21. Lamb, Charles W., Hair, Joseph F., and McDaniel, Carl. Pemasaran. Penerjamah David Octarevia. Jakarta : Salemba Empat. 2002.

22. Lesmana, Erik. Pemahaman Etika Bisnis Islam dan Tingkat Persaingan Usaha serta Perilaku Dagang. Konsentrasi Perbankan Syariah. UIN Syarif Hidayatullah : Jakarta. 2010.

23. Mujahidin, Akhmad. Etika Bisnis Dalam Islam “Analisis Terhadap Aspek Moral Pelaku Bisnis". Bandung. 2005.

24. Muslich. Etika Bisnis Islam, Jakarta : Ekonosia. 2004.

25. Naf'an. Ekonomi Makro : Tinjauan Ekonomi Syari'ah. Yogyakarta : Graha Ilmu. 2014.

26. Haider Naqvi, Syed Nawab. Etika Dan Ilmu Ekonomi Suatu Sintesis Islami. Bandung : Mizan. 1993.

27. Omar, O. E. Retail Marketing. Harlow, England : Perason Education. 1999.

28. Peter, J Paul., and Olson., Jerry C. Consumer Behavior. Perilaku Konsumen dan Strategi Pemasaran. Terjemahan Damos Sihombing. Jakarta : Jilid. Edisi 4, Erlangga. 2000.

29. Rini dkk. Analisis Pengaruh Locus Of Control Terhadap Kinerja Dengan Etika Kerja Islam Sebagai Variabel Moderating (Studi Pada Karyawan Tetap Bank Jateng Semarang). Jawa Tengah. 2010.

30. Qordhowi, Yusuf. Norma dan Etika Ekonomi Islam. Jakarta : Gema Insani Press. 1993.

31. Qordhawi, Yusuf. Halal dan Haram Dalam Islam, Terjemahan Muamammal Hamidy, Surabaya : Bina Ilmu. 1993.

32. Rafik Isa Beekun. Islamic Business Ethics. Virginia: international institute of Islamic thought. 1997

33. Shihab, Alwi. Islam inklusif. Bandung : Mizan. 1992.

34. Salam, Burhanudin. Etika Sosial Asas Moral Dalam Kehidupan Manusia. Jakarta : Rineka Cipta. 1997.

35. Sugiyono. Metode Penelitian Bisnis. Bandung : Alfabeta. 2004.

36. Wilkie, William L. Consumer Behavior. New York : Third Edition, John Wilem \& Sons Inc. 1994.

37. Yosephus, Sinuor.L. Etika Bisnis Pendekatan Filsafat Moral Terhadap Perilaku Pebisnis Kontemporer. Jakarta : Pustaka Obor Indonesia. 2010. 
74 | Amir Salim Analisis Pemahaman dan Penerapan Etika Bisnis Islam...

38. https://hanaqyen12.wordpress.com/2013/05/12/etika-bisnis-ekonomi-islam/. Diakses tanggal, 11 Oktober 2016.

39. http://zonaekis.com/prinsip-prinsip-dasar-dalam-etika-bisnis-islam/. Diakses tanggal, 11 Oktober 2016.

40. http://www.ilmu-ekonomi-id.com/2016/11/pengertian-segmentasi-pasar-tujuandan-contohnya.html. Diakses tanggal, 11 Oktober 2016

41. http://www.pengertianku.net/2015/04/pengertian-segmentasi-pasar-danmanfaatnya.html. Diakses tanggal, 11 Oktober 2016

42. http://www.bppk.kemenkeu.go.id/publikasi/artikel/150-artikel-keuanganumum/21129-mengenal-etika-dagang-syariah. Diakses tanggal, 11 Oktober 2016

43. https://learnourworld.wordpress.com/2011/08/24/etika-bisnis-dalam-islam/. Diakses tanggal, 11 Oktober 2016

44. http://zonaekis.com/larangan-larangan-dalam-etika-bisnis-islam/. tanggal, 11 Oktober 2016

Diakses

45. https://akmalaziz.wordpress.com/2014/01/09/pemasaran-dalam-perspektifislam/. Diakses tanggal, 11 Oktober 2016 